\title{
Factors Determining ARDS and Mortality in Covid-19 Pneumonia
}

\author{
Covid-19 Pnömonisinde ARDS ve Mortaliteyi Belirleyen Faktörler \\ Adnan Yamanoğlu, ๑Ejder Saylav Bora, $\odot$ Nalan Gökçe Çelebi Yamanoğlu, @Cüneyt Arıkan, \\ -Hüseyin Acar
}

Izmir Katip Çelebi University' Atatürk Research and Training Hospital, İzmir, Turkey

\begin{abstract}
Introduction: COVID-19 is caused by a newly discovered corona virus called severe acute respiratory syndrome coronavirus 2 (SARS-CoV-2). COVID-19 patients often present with fever, myalgia or fatigue and dry cough. Although most patients' prognosis is thought to be benign, it is known that poor results can be observed in elderly patients and those with chronic underlying diseases.

Our aim in this study is to investigate the factors that progress to ARDS and cause mortality in patients with COVID-19 pneumonia, based on symptoms, laboratory findings, Computed Tomography (CT) findings, chronic diseases and continuous medications they use.

Material and Method: Demographic characteristics of patients with Covid-19 pneumonia such as age, gender, complaints, vital signs, physical examination findings, smoking and other habits, chronic disease histories, laboratory and imaging examination results, treatment regimen applied in the hospital, hospitalization and intensive care durations were obtained and recorded in the hospital registration system. Clinical outcomes of all patients; Acute Respiratory Disitress (ARDS) has been recorded by classifying it as discharge or exitus. The definition of ARDS was made according to the Berlin criteria updated in 2012.

Result and Conclusion: In this study, low oxygen saturation at admission, chronic diuretic use, hypocalcemia, thrombocytopenia were found to be significant parameters that increase the risk for both ARDS and mortality in patients with Covid-19 pneumonia. In addition, high D-Dimer was found to be a significant risk factor for the development of ARDS, while advanced age was found to be a significant risk factor for mortality.
\end{abstract}

Keywords: Covid-19, ARDS, diuretic use, electrolyte disturbances

\begin{abstract}
Öz
Giriş: COVID-19, şiddetli akut solunum sendromu koronavirüs 2 (SARSCoV-2) adı verilen yeni keşfedilen bir korona virüsten kaynaklanır. COVID-19 hastaları genellikle ateş, miyalji, yorgunluk ve kuru öksürük ile başvurur. Çoğu hastanın prognozunun selim seyirli olacağı düşünülse de yaşlı hastalar ve kronik altta yatan rahatsızlıkları olanlar da kötü sonuçların gözlenebildiği bilinmektedir.

Bu çalışmada amacımız COVID-19 pnömonisi olan hastalarda ARDS'ye ilerleyen ve mortaliteye sebep olan faktörleri; semptomlar, laboratuvar bulguları, Bilgisayarlı Tomografi (BT) bulguları, kronik hastalıklar ve kullandıkları devamlı ilaçlardan yola çıkarak araştırmaktır.
\end{abstract}

Gereç ve Yöntem: Covid-19 pnomonisi olan hastaların yaş, cinsiyet gibi demografik özellikleri, şikayetleri, vital bulguları, fizik muayene bulguları, sigara kullanımı, kronik hastalık öyküleri kullandığı ilaçlar, laboratuvar, görüntüleme tetkik sonuçları, hastanede uygulanan tedavi rejimi, hastanede ve yoğun bakımda yatış süreleri hastane kayıt sisteminden elde edildi. Tüm hastaların klinik sonlanımları; Akut Respiratuvar Distres sendromu (ARDS) gelişip gelişmemesi, taburculuk veya exitus olarak sınıfladırılarak kayıt altına alınmıştır. ARDS tanımı 2012 yılında güncellenen Berlin kriterlerine göre yapılmıştır.

Bulgular ve Sonuç: Bu çalışmada Covid-19 pnomonisi olan hastalarda başvuru sırasındaki oksijen saturasyonu düşüklüğü, kronik diüretik kullanımı, hipokalsemi, trombositopeni hem ARDS hem de mortalite için riski artıran anlamlı parametreler olarak bulunmuştur. Ayrıca D-Dimer yüksekliği ARDS gelişimi için anlamlı risk faktörü olarak bulunurken, ileri yaş ise mortalite için anlamlı risk faktörü olarak bulunmuştur.

Anahtar kelimeler: Covid-19, ARDS, diuretik kullanımı, elektrolit bozuklukları

Corresponding (iletişim): Ejder Saylav Bora, Department of Emergency Medicine, Izmir Atatürk Training and Research Hospital, Izmir, Turkey E-mail (E-posta): saylavbora@hotmail.com 


\section{INTRODUCTION}

Coronavirus disease 2019 (COVID-19) is caused by a newly discovered corona virus called severe acute respiratory syndrome coronavirus 2 (SARS-CoV-2). COVID-19, has spread globally. ${ }^{[1,2]}$ According to World Health Organization (WHO) data, the number of confirmed COVID-19 cases as of January 1.2021 is 81947503 confirmed cases, with 1,808 041 deaths. [1] Due to the rapid spread of COVID-19, which has become a major global health problem and affects millions of people, the World Health Organization declared the "Internationally Significant Public Health Emergency" on January 30.2020 and the global "Pandemic statue" on March 11, 2020..$^{[2-4]}$

COVID-19 patients often present with fever, myalgia or fatigue and dry cough. Although most patients' prognosis is thought to be benign, it is known that poor results can be observed in elderly patients and those with chronic underlying diseases. ${ }^{[2]}$ Dyspnea and hypoxemia may develop in patients with severe disease within 1 week after the onset of the disease, and this situation can rapidly progress to acute respiratory distress syndrome (ARDS) or end organ failure. ${ }^{[3]}$

Although this disease has a wide spectrum, it is not fully known why it is asymptomatic in some people and symptomatic in some. ${ }^{[3]}$ Major morbidity and mortality of hospitalized COVID-19 patients is due to acute viral pneumonia leading to acute respiratory distress syndrome (ARDS). ${ }^{[1,2,5]}$ The average mortality among COVID-19 patients with ARDS in all countries is $39 \% \cdot{ }^{[4]}$ Although it is said that the ARDS predisposing factors of COVID-19 are advanced age, neutrophilia, high D-dimer levels and comorbidities. ${ }^{[4]}$, studies have been analyzed on very new and few patients.

Our aim in this study is to investigate the factors that progress to ARDS and cause mortality in patients with COVID-19 pneumonia, based on symptoms, laboratory findings, Computed Tomography (CT) findings, chronic diseases and continuous medications they use.

\section{MATERIAL AND METHOD}

\section{Study design and Setting}

This study was carried out retrospectively observationally in the Covid-19 outpatient clinic of a tertiary education and research hospital. The study consists of patients who applied to the Covid outpatient clinic between March of 2020 and 2021 and were hospitalized after being diagnosed with Covid-19. Patient data were analyzed retrospectively. Before starting the study, consent was obtained from the hospital local ethics committee with the required number 711 .

\section{Study Population}

All patients admitted to our hospital's COVID-19 outpatient clinic, diagnosed with COVID-19, confirmed by the RT-qPCR test result and detected pneumonia in imaging were included in the study. Patients who were younger than 18 years old, who had no respiratory symptoms, who did not have lung imaging, and who had no pneumonic infiltration in the thorax even if the RT-qPCR test was positive were excluded from the study.

\section{Data Collection and processing}

Demographic features such as age, gender, complaints, vital signs of patients with Covid-19 pneumonia, physical examination findings, smoking, other habits, chronic disease, drugs used, laboratory, imaging test results, the treatment regimen applied in the hospital, the length of stay in the hospital and intensive care unit were obtained and recorded in the hospital registry system. Clinical outcomes of all patients; acute respiratory distress syndrom (ARDS) has been recorded by classifying it as discharge or exitus.

\section{Outcome Measures}

The primary outcome of the study was the development of ARDS in patients with Covid-19 pneumonia. The definition of ARDS was made according to the Berlin criteria. ${ }^{[6]}$ Updated in 2012 and stated below. It is aimed to determine the risk factors for the development of ARDS in patients with Covid-19 pneumonia. The secondary outcome of the study was the terms of survival and death. It was aimed to determine the factors affecting mortality in patients with Covid-19 pneumonia.

\section{Berlin Criteria}

1. Acute onset (over 1 week or less)

2. Bilateral opacities consistent with pulmonary edema must be present on $\mathrm{CT}$ or chest radiograph

3. $\mathrm{PaO}_{2} / \mathrm{FIO}_{2}$ ratio $<300 \mathrm{mmHg}$ with a minimum of $5 \mathrm{cmH}_{2} \mathrm{O}$ PEEP (or CPAP)

4. "must not be fully explained by cardiac failure or fluid overload," in estimation using available information-an "objective assessment" (e.g. echocardiogram)

\section{Statistical Analysis}

Descriptive statistics were expressed as frequency, percentage, mean, standard deviation, median, minimum and maximum values. Number and percentage values were calculated for categorical variables. Mean, standard deviation, minimum and maximum values and interquartile range (IQR) were calculated for numerical variables. Histogram curves, kurtosis and skewness values and Shapiro-Wilk test were used to determine whether the data were normally distributed. Normally distributed parameters were expressed as mean and standard deviation, and nonnormally distributed variables were expressed as median and minimum-maximum values.

Patients with Covid-19 pneumonia were divided into two groups as patients with and without ARDS. Age, gender, vital signs, chronic diseases, and laboratory findings of these two groups were compared. In this comparison, the categorical variables were compared with the chi-square test and the Student- $t$ test if the numerical variables provided the normal distribution, and the Mnnn-Whitney - $u$ test if they did not. The areas under the curve and the cut-off values separating the two groups were determined by drawing the ROC curve separately for all parameters. 
Regression analysis was used to analyze the power of all parameters found to be significant in these analyzes to predict the going to ARDS in Covid-19 pneumonia. First, all the parameters found to be significant were evaluated one by one in the univariate regression analysis, and all the parameters found to be statistically significant were included in the model in the multivariate logistic regression analysis, and their value in predicting ARDS access was calculated. Likewise, all patients were divided into two groups according to the clinical outcome of survival and death.

The power of all parameters, which showed a significant difference between the groups in the dual analysis, was drawn again by drawing the ROC curve, and the areas under the curve and cut-off values were calculated. All parameters that were successful in these analyzes were first tested in univariate regression alalysis.

A model was created from all significant parameters and the ability of this model to predict mortality in Covid-19 pneumonia was evaluated in multivariate logistic regression analysis. All statistical calculations were done on SPSS 23.0 (SPSS Inc., Chicago, IL, USA) for Windows software. All analyzes were done at a $95 \%$ confidence interval and $p$ values of $<0.05$ were considered statistically significant.

\section{RESULTS}

Patients diagnosed with Covid pneumonia (434 patients), including 190 (44\%) female and 244 (56\%) male patients, were included in this study. The average age of all patients with Covid-19 pneumonia was $53 \pm 19.164(38 \%)$ of 434 patients had at least one chronic disease. 59 (14\%) of 434 patients with Covid pneumonia had ARDS clinic and 48 (11\%) died. The mean initial oxygen saturation of patients with COVID-19 pneumonia was $96 \pm 4$, while the admission oxygen saturation of patients who progressed to ARDS was $84 \pm 7$, and the admission oxygen saturation of the patients who died was $84 \pm 8$. The demographic characteristics, complaints and vital signs and laboratory parameters of the patients are presented in Table 1.

ARDS developed in 59 of 434 patients with Covid pneumonia. Age, blood pressure at presentation and oxygen saturation were statistically significantly different between the group that developed ARDS and the group that did not. The comparison of the general characteristics, laboratory parameters and medical history of the group that developed ARDS and the groups that did not are presented in Table $\mathbf{2}$.

48 (11\%) of the 434 patients with Covid-19 pneumonia died. All demographic data and laboratory parameters of patients with exitus and living patients were compared. Age, blood pressure, oxygen saturation at presentation, prodictive cough at presentation, myalgia and dyspnea were found to be statistically significantly different between the deceased and the surviving patients. In addition to these parameters, the comparison of laboratory findings and medical history data between the groups is presented in Table 3.
Table 1. General characteristics, vital signs and laboratuvar findings of subjects

\begin{tabular}{|c|c|c|c|}
\hline Parameters & $\begin{array}{c}\text { Total } \\
\text { Patients } \\
\text { (with } \\
\text { Covid-19 } \\
\text { pneumonia) }\end{array}$ & $\begin{array}{c}\text { Patients } \\
\text { with ARDS }\end{array}$ & $\begin{array}{c}\text { Dying } \\
\text { patients }\end{array}$ \\
\hline
\end{tabular}

\section{General characteristics \&Vital signs}

No.

Age y (mean \pm SD)

Male $\mathrm{n}(\%)$

Female $\mathrm{n}(\%)$

Siistolik BP $(\mathrm{mm} \mathrm{Hg})$

Diastolik BP (mm Hg)

Admission oxygen saturation (\%)

Admission symptoms

Fever (C)

Throat ache (\%)

Myalgia (\%)

Diarrhea (\%)

Runny nose (\%)

Dry cough (\%)

Productive cough (\%)

Dyspnea (\%)

Laboratory analysis

WBC $\left({ }^{*} 10^{9} / \mathrm{L} \mathrm{wbc} / \mathrm{mcL}\right)$

Neutrophil $\left({ }^{*} 10^{3}\right.$ neut $\left./ \mathrm{mcL}\right)$

Lymphocyte $\left({ }^{*} 10^{3} \mathrm{lym} / \mathrm{mcL}\right)$

Platelet $\left({ }^{*} 10^{3} \mathrm{plt} / \mathrm{mcL}\right)$

$\mathrm{K}+(\mathrm{mmol} / \mathrm{l})$

$\mathrm{Ca}+(\mathrm{mg} / \mathrm{dL})$

$\mathrm{Na}+(\mathrm{mEq} / \mathrm{L})$

AST (IU/L)

ALT (IU/L)

BUN (mg/dL)

Lactate $(\mathrm{mmol} / \mathrm{L})$

Troponin (ng/ml)

D-Dimer $(\mathrm{mcg} / \mathrm{mL})$

Ferritin (ng/mL)

Medical history

CHF n (\%)

$\mathrm{DM} n(\%)$

CRF n (\%)

COPD (\%)

HT (\%)

CAD (\%)

Cancer (\%)

Alzheimer and dementia (\%)

\section{Medication}

ACEl inhibitors (\%)

Diuretic (\%)

Anticoagulant (\%)

Ca Channel Blocker (\%)

BC: White

ure nitrote aminotransferase, ALT: Alanine aminotransferase, BUN: Blood Chornic Chornic obstructive pulmonary disease, HT: Hype
Angiotensin-converting enzyme (ACE) inhibitors

$\begin{array}{ccc}434 & 59 & 48 \\ 53 \pm 19 & 68 \pm 18 & 71 \pm 17 \\ 56 & 58 & 63 \\ 44 & 42 & 38 \\ 122 \pm 18 & 111 \pm 17 & 110 \pm 17 \\ 74 \pm 13 & 68 \pm 12 & 67 \pm 12 \\ 96 \pm 4 & 84 \pm 7 & 84 \pm 8 \\ & & \\ 38 \pm 0.6 & 37 \pm 08 & 36.9 \pm 0.9 \\ 17.3 & 15.3 & 14.6 \\ 29.5 & 20,3 & 47.9 \\ 6.9 & 3.2 & 8.3 \\ 4.8 & 5.1 & 2.1 \\ 49.5 & 76.3 & 72.9 \\ 8.1 & 11.9 & 20.8 \\ 25.8 & 93.2 & 93.8 \\ & & \\ 6.6 \pm 3 & 9 \pm 6 & 9.5 \pm 6.6 \\ 4.6 \pm 5 & 7.4 \pm 5 & 7.8 \pm 5.4 \\ 1.7 \pm 1.1 & 1.6 \pm 2.4 & 1.6 \pm 1 \\ 227 \pm 89 & 148 \pm 64 & 153 \pm 64 \\ 4.1 \pm 0.5 & 4.3 \pm 0.9 & 4.3 \pm 0.9 \\ 8.5 \pm 0.7 & 7.5 \pm 0.5 & 9 \pm 7,4 \\ 137.3 \pm 4 & 136 \pm 5.6 & 136 \pm 6 \\ 40 \pm 117 & 132.6 \pm 44 & 154 \pm 52 \\ 45 \pm 217 & 136 \pm 30 & 161 \pm 38 \\ 17 \pm 13 & 32 \pm 27 & 35.3 \pm 24 \\ 1.7 \pm 17.3 & 2.3 \pm 1.6 & 2.5 \pm 2.7 \\ 0.69 \pm 0.55 & 0.36 \pm 0.02 & 0.44 \pm 0.29 \\ 502 \pm 997 & 2077 \pm 1874 & 2080 \pm 1167 \\ 350 \pm 469 & 999 \pm 88 & 1020 \pm 790\end{array}$

\begin{tabular}{ccc}
3.9 & 5.1 & 6.3 \\
17.1 & 20.3 & 25 \\
3.7 & 5.1 & 6.3 \\
11.1 & 18.6 & 16.7 \\
17.1 & 33.9 & 41.7 \\
9 & 15.3 & 16.7 \\
3 & 11.9 & 10.4 \\
2.3 & 8.5 & 10.4 \\
& & \\
13.6 & 22 & 27.1 \\
9 & 30.5 & 33.3 \\
14.7 & 28.8 & 33.3 \\
12.2 & 6.8 & 8.3 \\
\hline
\end{tabular}
sion, CAD: Coronary artery disease, ACEI: 
Table 2. Comparison of data of patients with Covid-19 pneumonia with and without ARDS

\begin{tabular}{|c|c|c|c|}
\hline Parameters & $\begin{array}{c}\text { Patients } \\
\text { with ARDS } \\
\mathrm{n}: 58\end{array}$ & $\begin{array}{c}\text { Patients } \\
\text { without ARDS } \\
\text { n:373 }\end{array}$ & $\mathbf{p}$ \\
\hline \multicolumn{4}{|c|}{ General characteristics \&Vital signs } \\
\hline Age y (mean $\pm S D)$ & $68 \pm 18$ & $51 \pm 18$ & $<0.001$ \\
\hline Gender F n (\%) & $25(13 \%)$ & $165(87 \%)$ & \multirow{2}{*}{0.815} \\
\hline$M n(\%)$ & $34(14 \%)$ & $210(86 \%)$ & \\
\hline Systolic BP (mm Hg) & $111 \pm 17$ & $123 \pm 15$ & $<0.001$ \\
\hline Diastolic BP (mm Hg) & $68 \pm 12$ & $75 \pm 9.8$ & $<0.001$ \\
\hline Admission oxygen saturation (\%) & $85 \pm 7$ & $97 \pm 2.3$ & $<0.001$ \\
\hline \multicolumn{4}{|l|}{ Admission symptoms } \\
\hline Fever (C) & $36.8 \pm 0.8$ & $36.7 \pm 0.7$ & 0.487 \\
\hline Throat ache (\%) & $9(15.5 \%)$ & $66(17.7 \%)$ & 0.684 \\
\hline Myalgia (\%) & 29 & 99 & $<0.001$ \\
\hline Diarrhea (\%) & $7(12 \%)$ & $23(6 \%)$ & 0.10 \\
\hline Runny nose (\%) & $3(3.2 \%)$ & $18(4.8 \%)$ & 0.909 \\
\hline Dry cough (\%) & $45(76 \%)$ & $174(47 \%)$ & $<0.001$ \\
\hline Productive cough (\%) & $12(21 \%)$ & $23(6 \%)$ & $<0.001$ \\
\hline Dyspnea (\%) & 55 (93\%) & $80(22 \%)$ & $<0.001$ \\
\hline \multicolumn{4}{|l|}{ Laboratory analysis } \\
\hline WBC $\left({ }^{*} 10^{9} / \mathrm{L} \mathrm{wbc} / \mathrm{mcL}\right)$ & $9.1 \pm 5.9$ & $6.3 \pm 2.4$ & 0.002 \\
\hline Neutrophil ( ${ }^{*} 10^{3}$ neut $\left./ \mathrm{mcL}\right)$ & $7.4 \pm 5.8$ & $4.3 \pm 4.8$ & $<0.001$ \\
\hline Lymphocyte(* $10^{3}$ lym/mcL) & $1.6 \pm 2.4$ & $1.7 \pm 0.7$ & $<0.001$ \\
\hline Platelet $\left(* 10^{3} \mathrm{plt} / \mathrm{mcL}\right)$ & $148 \pm 64$ & $239 \pm 86$ & $<0.001$ \\
\hline $\mathrm{K}+(\mathrm{mmol} / \mathrm{l})$ & $4.3 \pm 0.9$ & $4.1 \pm 0.39$ & 0.016 \\
\hline $\mathrm{Ca}+(\mathrm{mg} / \mathrm{dL})$ & $7.5 \pm 0.4$ & $8.9 \pm 3.8$ & $<0.001$ \\
\hline $\mathrm{Na}+(\mathrm{mEq} / \mathrm{L})$ & $136 \pm 5.6$ & $138 \pm 3.6$ & 0.010 \\
\hline AST (IU/L) & $133 \pm 510$ & $28 \pm 22$ & $<0.001$ \\
\hline ALT (IU/L) & $137 \pm 614$ & $33 \pm 47$ & 0.046 \\
\hline BUN (mg/dL) & $32 \pm 27$ & $15 \pm 7.6$ & $<0.001$ \\
\hline Lactate (mmol/L) & $2.3 \pm 2.2$ & $1.4 \pm 0.6$ & 0.138 \\
\hline Troponin (ng/ml) & $0.36 \pm 1.4$ & $0.018 \pm 0.058$ & $<0.001$ \\
\hline D-Dimer (mcg/mL) & $2078 \pm 1875$ & $357 \pm 628$ & $<0.001$ \\
\hline Ferritin $(\mathrm{ng} / \mathrm{mL})$ & $999 \pm 851$ & $262 \pm 300$ & $<0.001$ \\
\hline \multicolumn{4}{|l|}{ Medical history } \\
\hline CHF n (\%) & $3(7 \%)$ & $14(4 \%)$ & 0.374 \\
\hline DM n (\%) & $12(27 \%)$ & $62(17 \%)$ & 0.100 \\
\hline CRF n (\%) & $3(7 \%)$ & $13(4 \%)$ & 0.317 \\
\hline COPD (\%) & $11(25 \%)$ & 37 (10\%) & 0.030 \\
\hline HT (\%) & $20(44 \%)$ & $96(26 \%)$ & 0.012 \\
\hline CAD (\%) & $9(20 \%)$ & $30(8 \%)$ & 0.012 \\
\hline Cancer (\%) & $7(15 \%)$ & $6(2 \%)$ & $<0.001$ \\
\hline Alzheimer and dementia (\%) & $5(11 \%)$ & $5(1 \%)$ & $<0.001$ \\
\hline \multicolumn{4}{|l|}{ Medication } \\
\hline ACEI inhibitors (\%) & $13(28 \%)$ & $46(13 \%)$ & 0.004 \\
\hline Diuretic (\%) & $21(36 \%)$ & $24(7 \%)$ & $<0.001$ \\
\hline Anticoagulant (\%) & $10(17 \%)$ & $12(3 \%)$ & $<0.001$ \\
\hline Ca Channel Blocker (\%) & 4 (9\%) & $49(13 \%)$ & 0.380 \\
\hline
\end{tabular}

WBC: White Blood Cell, AST: Aspartate Aminotransferase, ALT: Alanine Aminotransferase, BUN: Blood Urea Nitrogen, CHF: Chronic Heart Failure, DM : Diabetes Mellitus, CRF : Chronic Renal Failure, COPD: Chornic Obstructive Pulmonary Disease, HT: Hypertension, CAD: Coronary artery disease, ACEI: Angiotensin-converting enzyme (ACE) inhibitors
Table 3. Comparison of data of patients with Covid pneumonia by clinical outcome in terms of survival and death

\begin{tabular}{lccc} 
Parameters & $\begin{array}{c}\text { Dying } \\
\text { patients } \\
\text { n:48 }\end{array}$ & $\begin{array}{c}\text { Surviving } \\
\text { patients } \\
\text { n:387 }\end{array}$ & p \\
\hline General characteristics \&Vital signs & & & \\
Age y (mean \pm SD) & $71 \pm 17$ & $51 \pm 18$ & $<0.001$ \\
Gender F n (\%) & $18(10 \%)$ & $172(90 \%)$ & \\
M n (\%) & $30(12 \%)$ & $214(88 \%)$ & 0.353 \\
Systolic BP (mm Hg) & $110 \pm 17$ & $123 \pm 15$ & $<0.001$ \\
Diastolic BP (mm Hg) & $67 \pm 12$ & $75 \pm 10$ & $<0.001$ \\
Admission oxygen saturation (\%) & $84 \pm 8$ & $97 \pm 3$ & $<0.001$
\end{tabular}

\section{Admission symptoms}

Fever (C)

Throat ache $\mathrm{n}(\%)$

Myalgia $\mathrm{n}(\%)$

Diarrhea $\mathrm{n}(\%)$

Runny nose $\mathrm{n}(\%)$

Dry cough $\mathrm{n}(\%)$

Productive cough $\mathrm{n}(\%)$

Dyspnea $\mathrm{n}(\%)$

\section{Laboratory analysis}

WBC $\left(* 10^{9} / \mathrm{L} \mathrm{wbc} / \mathrm{mcL}\right)$

Neutrophil $\left(* 10^{3}\right.$ neut $/ \mathrm{mcL}$ )

Lymphocyte $\left({ }^{*} 10^{3} \mathrm{lym} / \mathrm{mcL}\right)$

Platelet $\left({ }^{*} 10^{3} \mathrm{plt} / \mathrm{mcL}\right)$

$\mathrm{K}+(\mathrm{mmol} / \mathrm{l})$

$\mathrm{Ca}+(\mathrm{mg} / \mathrm{dL})$

$\mathrm{Na}+(\mathrm{mEq} / \mathrm{L})$

AST (IU/L)

ALT (IU/L)

BUN (mg/dL)

Lactate (mmol/L)

Troponin (ng/ml)

D-Dimer $(\mathrm{mcg} / \mathrm{mL})$

Ferritin $(\mathrm{ng} / \mathrm{mL})$

\section{Medical history}

CHF n (\%)

DM n (\%)

CRF n (\%)

COPD n (\%)

HT n (\%)

CAD n (\%)

Cancer $\mathrm{n}(\%)$

Alzheimer and dementia (\%)

\section{Medication}

ACEI inhibitors (\%)

Diuretic (\%)

Anticoagulant (\%)

$\begin{array}{ccc}36.9 \pm 0.9 & 36.7 \pm 0.7 & 0.511 \\ 7(14 \%) & 68(18 \%) & 0.631 \\ 23(27 \%) & 105(49 \%) & 0.002 \\ 4(9 \%) & 26(7 \%) & 0.658 \\ 1(2 \%) & 20(5 \%) & 0.354 \\ 35(\%) & 184(\%) & 0.001 \\ 10(21 \%) & 25(8 \%) & <0.001 \\ 45(94 \%) & 90(24 \%) & <0.001 \\ & & \\ 9.5 \pm 6.3 & 6.3 \pm 2.4 & 0.006 \\ 7.8 \pm 6.2 & 4.3 \pm 4.7 & <0.001 \\ 1.6 \pm 2.7 & 1.7 \pm 0.8 & <0.001 \\ 153 \pm 65 & 237 \pm 88 & <0.001 \\ 4.3 \pm 0.9 & 4.1 \pm 0.4 & 0.52 \\ 9 \pm 2 & 8.6 \pm 0.6 & <0.001 \\ 136 \pm 6 & 137 \pm 4 & 0.112 \\ 155 \pm 561 & 28 \pm 21 & <0.001 \\ 161 \pm 675 & 32 \pm 46 & 0.02 \\ 35 \pm 29 & 15 \pm 8 & <0.001 \\ 2.5 \pm 2.3 & 1.4 \pm 0.6 & 0.035 \\ 0.4 \pm 1.5 & 0.01 \pm 0.05 & <0.001 \\ 2081 \pm 2038 & 406 \pm 698 & <0.001 \\ 1021 \pm 880 & 273 \pm 322 & <0.001 \\ & & <0.0 .001 \\ 3(8 \%) & 14(4 \%) & 0.212 \\ 12(25 \%) & 62(16 \%) & 0.015 \\ 3(8 \%) & 13(3 \%) & 0.173 \\ 8(17 \%) & 40(10 \%) & 0.036 \\ 20(53 \%) & 96(25 \%) & <0.001 \\ 8(21 \%) & 31(8 \%) & 0.009 \\ 5(13 \%) & 8(2 \%) & <0.001 \\ 5(13 \%) & 5(1 \%) & <0.001 \\ 13(34 \%) & 26(12 \%) & <0.001 \\ 19(40 \%) & 46(7 \%) & <0.001 \\ 16(41 \%) & 48(12 \%) & <0.001 \\ 4(11 \%) & 49(13 \%) & 0.665\end{array}$

Ca Channel Blocker (\%)

WBC: White Blood Cell, AST: Aspartate Aminotransferase, ALT: Alanine Aminotransferase, BUN: Blood Urea Nitrogen, CHF: Chronic Heart Failure, DM : Diabetes Mellitus, CRF : Chronic Renal Failure, COPD: Chornic Obstructive Pulmonary Disease, HT: Hypertension, CAD: Coronary artery disease, ACEl: Angiotensin-converting enzyme (ACE) inhibitors 
First of all, all parameters in Table 2, which were found to be statistically significantly different between the group with ARDS and the group without ARDS, were tested in the univariate logistic regression analysis. The age of the patients, the oxygen saturation value obtained from the patients at the time of admission, blood calcium value, platelet value, D-Dimer value and the data of chronic diuretic use of the patients were found to be statistically significant $(p<0.005)$ in the univariate logistic regression analysis. The sensitivity and specificity of these parameters to detect ARDS and the results of the logistic regression model created from these parameters are presented in Table 4. In the regression analysis, it was seen that the age parameter was a confounding factor. The model consisting of oxygen saturation, calcium, platelet, d-dimer and diuretic use was strong enough to detect 50\% of all ARDS events according to Cox \& Snell R Square, and the overall percentage of success of the model for predicting all events was found to be $86.2 \%$.

Factors determining the course of mortality in patients were tested using logistic regression analysis. First of all, all parameters in Table 3 that were found to be statistically significantly different between patients who died and those who survived were tested in the univariate logistic regression analysis. The age of the patients, the oxygen saturation value, blood calcium value, platelet value, D-Dimer value and the chronic diuretic use of the patients were found to be statistically significant $(p<0.005)$ in univariate logistic regression analysis. The sensitivity and specificity of these parameters calculated to determine mortality and the results of the logistic regression model created from these parameters are presented in Table 5. After making age related corrections D-Dimer was found to be a confounding factor in the regression analysis. According to the Cox \& Snell R Square, the model consisting of oxygen saturation, calcium, platelet, d-dimer and diuretic use was strong enough to explain $38 \%$ of all cases resulting in mortality, and the overall percentage of success of the model in predicting all events was found to be $94 \%$.

\section{DISCUSSION}

434 patients diagnosed with Covid pneumonia, including 190 (44\%) female and 244 (56\%) male patients, were included in this study, 59 of these patients (14\%) developed ARDS clinic and 48 (11\%) died. The 22 parameters shown in Table 2 were found to be statistically significant between patients who developed ARDS and those who did not. However, in regression analysis, low oxygen saturation at admission, chronic diuretic use, low laboratory calcium level, low platelet level and high D-dimer value were found to be significant risk factors in the development of ARDS in patients with covid pneumonia. Among these parameters, the highest risk was found in relation to the use of diuretics. Diuretic use was found to be associated with an approximately 13-times increased risk of developing ARDS. However, in the analyzes we conducted to determine the factors determining mortality in Covid-19 patients, the 24 parameters seen in table 3 were statistically significant between the patients who died and survived. However, among these parameters, elderly patients, low oxygen saturation at the time of admission, chronic diuretic use, laboratory calcium, and low platelet levels were found among significant risk factors for mortality in Covid-19 pneumonia. Among these parameters, the use of diuretics was found to be the most significant parameter, creating approximately 6 times (Exb: 1/0.154) risk for mortality.

ARDS is one of the major complications of Covid-19. Among the application complaints of patients with severe Covid-19 pneumonia and ARDS, dyspnea was stated as the most common complaint. ${ }^{[7]}$ In our study, 55 (93\%) of 59 patients who developed ARDS had dyspnea at presentation. In their study with patients with Covid-19 pneumonia, Hu et al. ${ }^{[8]}$ reported that $20 \%$ of patients developed ARDS and $12 \%$ needed a mechanical ventilator. In our study, it was observed that 59 (13.4\%) of 434 patients with Covid-19 pneumonia developed ARDS and our data were found to be compatible with the reports of Hu et al. ARDS is a clinical syndrome with a mortality rate of more than $50 \%$ and characterized by hypoxia and

Table 4. Multivariate Logistic Regression analysis to predict ARDS in patients with Covid-19 Pneumonia

\begin{tabular}{|c|c|c|c|c|c|c|c|c|c|}
\hline ARDS & B & Exb (ods r) & $\mathrm{Cl}(\% 95)$ Upper bound & $\mathrm{Cl}(\% 95)$ Lower bound & $\mathbf{P}$ & Cut-off & Sensitivity & Specificity & AUC \\
\hline Sat $\mathrm{O}_{2}$ & -0.822 & 0.44 & 0.304 & 0.637 & $<0.001$ & 88.5 & 0.458 & 0.011 & 0.019 \\
\hline $\mathrm{Ca}^{++}$ & -1.051 & 0.35 & 0.146 & 0.836 & 0.018 & 7.45 & 0.508 & 0.019 & 0.049 \\
\hline Plt & -0.028 & 0.973 & 0.958 & 0.987 & $<0.001$ & 152500 & 0.458 & 0.125 & 0.172 \\
\hline D-dimer & 0.001 & 1.001 & 1 & 1.001 & 0.034 & 351 & 0.915 & 0.709 & 0.899 \\
\hline Age & 0.001 & 1.001 & 0.96 & 1.043 & 0.979 & 56.5 & 0.746 & 0.635 & 0.753 \\
\hline Diuretic use & 2.585 & 13.265 & 1.898 & 92.707 & 0.009 & 0.5 & 0.356 & 0.062 & 0.647 \\
\hline
\end{tabular}

AUC: Area under the curve, ARDS: Acute respiratory distress syndrome, Ca++: Calcium, Sat O2 : Saturation of Oxygen, Plt: Platelet

\begin{tabular}{|c|c|c|c|c|c|c|c|c|c|}
\hline Mortality & B & Exb (ods r) & $\mathrm{Cl}(\% 95)$ Lower bound & Cl (\%95) Upper bound & $\mathbf{P}$ & Cut-off & Sensitivity & Specificity & AUC \\
\hline Plt & -0.01 & 0.99 & 0.985 & 0.996 & 0.001 & 152500 & 0.511 & 0.142 & 0.213 \\
\hline Age & 0.037 & 1.038 & 1.006 & 1.072 & 0.021 & 64.5 & 0.73 & 0.761 & 0.788 \\
\hline Diuretic use & -1.87 & 0.154 & 0.046 & 0.512 & 0.002 & 0.5 & 0.356 & 0.068 & 0.644 \\
\hline D-dimer & 0 & 1 & 1 & 1.001 & 0.333 & 334.5 & 0.991 & 0.682 & 0.863 \\
\hline Sat $\mathrm{O}_{2}$ & -0.408 & 0.665 & 0.579 & 0.764 & 0.001 & 81 & 0.644 & 0.008 & 0.024 \\
\hline $\mathrm{Ca}^{++}$ & -2.728 & 0.065 & 0.034 & 0.127 & 0.001 & 7.94 & 0.21 & 0.101 & 0.054 \\
\hline
\end{tabular}


pulmonary damage. ${ }^{[8]}$ In this syndrome, the pulmonary barrier is disrupted; permeability, inflammation, cellular infiltration and exudation are increased; necrosis occurs; as a result, ventilation and perfusion are impaired..$^{[3]}$ It is known that lung damage and ARDS are the main factors that cause death in patients with Covid-19 disease. In our population, only one of 48 patients who died did not develop ARDS. It was observed that 47 (79\%) of 59 patients with ARDS died. According to the results of our study, the mortality of patients who developed ARDS due to Covid-19 pneumonia was found to be $79 \%$. This shows us that ARDS developing due to Covid-19 may have a more mortal course than ARDS caused by other reasons.

While COVID-19 may progress with an asymptomatic or mild clinical course in some patients, ${ }^{[9,10]}$ it may cause severe respiratory failure and death in some patients. ${ }^{[1,12]}$ The reason for the different severity of the disease among individuals has not been fully elucidated yet. However, it has been previously reported that comorbidities, ${ }^{[11,13]}$ advanced age, ${ }^{[14]}$ and male gender $^{[15]}$ may be factors indicating that the disease may progress to a severe course. In later studies, it was reported that high D-Dimer levels, ${ }^{[16]}$ hypocalcemia, ${ }^{[17]}$ and low platelets, ${ }^{[18]}$ may be associated with the severity and mortality of the disease. In our study, among these parameters, thrombocytopenia and hypocalcemia were found to be risk factors for both ARDS and mortality. In addition, D-dimer level was found to be associated with the development of ARDS in parallel with these studies, while advanced age was also found to be associated with mortality, similar to other studies. In our study, the severe course of the disease and the factors affecting mortality are largely similar to the literature. Unlike the literature, chronic diuretic use has been found to be an important risk factor for both mortality and ARDS. There are previous studies claiming that the use of angitensin converting enzyme inhibitors (ACEls) may be associated with poor outcome in Covid-19 patients, ${ }^{[19]}$ as well as studies claiming to be unrelated. ${ }^{[20]}$ There are rare studies evaluating the effect of diuretic use on Covid-19. In these studies, it is reported that the use of in-hospital diuretics is associated with poor outcome in Covid-19. ${ }^{[21]}$ Covid-19 pneumonia is a disease that can progress with taste disturbance, fever, and loss of appetite. Therefore, it is possible that the tendency to dehydration will increase in these patients with a decrease in oral intake and an increase in insensible losses with possible fever. Especially in elderly patients with comorbidities and who have a high tendency to be complicated, the tendency to dehydration is likely to increase with Covid-19 pneumonia. Presence of additional diuretic use in these patients may increase diuresis and the resulting dehydration may lead to circulatory disturbance and shock. Therefore, as in our population, the use of diuretics in patients with Covid-19 pneumonia may be associated with mortality, albeit indirectly.

The relationship between hypocalcemia and Covid-19 disease has been evaluated in many studies. Hypocalcemia has been recently identified as one of the major biochemical features of COVID-19 patients. ${ }^{[3,4,25]}$ Until now, both low ionized and low total calcium levels have frequently been reported in emergency rooms (ED) and hospitalized patients. ${ }^{[4,25]}$ Moreover, a strong association between lower calcium and higher inflammatory parameters and increased disease severity has also been reported. ${ }^{[4]}$ In addition, some authors defined hypocalcemia as a relevant and independent risk factor for worse clinical outcome, including hospitalization rate, intensive care unit admission, and mortality. ${ }^{[4,22,23]}$ Calcium is an essential ion for the survival of pathogens and virulence and plays a role in regulating the inflammatory response, and hypocalcemia is a common laboratory finding in critically ill patients. ${ }^{[2]}$ In our study, in accordance with the literature, hypocalcemia was found to be associated with mortality and ARDS.

It is known that the coagulation system is affected in COVID-19, while the D-dimer and prothrombin time increase, the platelet value decreases. D-Dimer is one of the most studied prognostic factors on this subject. Numerous studies have reported a high number of venous thromboembolism (VTE), especially in patients with severe COVID-19. ${ }^{[26]}$ Coagulopathy caused by COVID-19 manifests itself with an increase in D-dimer and fibrin/fibrinogen levels and a decrease in platelet count. ${ }^{[26]}$ In our study, while high D-dimer levels were found to be associated with ARDS, thrombocytopenia was found to be closely related to both ARDS and mortality. These data we obtained in our study are consistent with the present findings in the literature.

\section{Limitation}

The most important limitation of this study is that it was conducted with a relatively low number of patients in a global epidemic such as a pandemic, and as in all retrospective studies, it was conducted through patient records.

\section{CONCLUSION}

In this study, low oxygen saturation, chronic diuretic use, hypocalcemia and thrombocytopenia were found to be significant parameters that increase the risk for both ARDS and mortality in patients with Covid-19 pneumonia. In addition, high D-Dimer was found to be a significant risk factor for the development of ARDS, while advanced age was found to be a significant risk factor for mortality.

\section{ETHICAL DECLARATIONS}

Ethics Committee Approval: İzmir Katip Çelebi University Non-Interventional Clinical Studys Institutional Review Board (date: 12.05.2020 number: 711).

Informed Consent: Because the study was designed retrospectively, no written informed consent form was obtained from patients.

Referee Evaluation Process: Externally peer-reviewed.

Conflict of Interest Statement: The author(s) declared no potential conflicts of interest with respect to the research, authorship, and/or publication of this article. 
Financial Disclosure: The authors declared that this study has received no financial support.

Author Contributions: All of the authors declare that they have all participated in the design, execution, and analysis of the paper, and that they have approved the final version.

\section{REFERENCES}

1. Guan WJ, Ni ZY, Hu Y, et al. Clinical characteristics of coronavirus disease 2019 in China. N Engl J Med 2020;382:1708-20.

2. Huang C, Wang Y, Li X, et al. Clinical features of patients infected with 2019 novel coronavirus in Wuhan, China. Lancet 2020;395:497-506

3. Chen N, Zhou M, Dong X, et al. Epidemiological and clinical characteristics of 99 cases of 2019 novel coronavirus pneumonia inWuhan, China: a descriptive study. Lancet. 2020;395(10223):507-13.

4. Hasan SS, Capstick T, Ahmed R, et al. Mortality in COVID-19 patients with acute respiratory distress syndrome and corticosteroids use: a systematic review and meta-analysis. Expert Rev Respir Med. 2020;14(11):1149-63.

5. World Health Organization. Clinical management of severe acute respiratory infection when novel coronavirus (nCoV) infection is suspected: interim guidance. January 28, 2020. Accessed March 5, 2020

6. ARDS Definition Task Force, Ranieri VM, Rubenfeld GD, et al. Acute respiratory distress syndrome: the Berlin Definition. JAMA 2012;307:252633.

7. Hu B, Hu C, Zhu F, et al. Clinical Characteristics of 138 Hospitalized Patients With 2019 Novel Coronavirus-Infected Pneumonia in Wuhan, China. JAMA. 2020;323(11):1061.

8. DG, Bigelow DB, Petty $T L$, Levine BE acute respiratory distress in adults. Ashbaugh Lancet. 1967;2(7511):319

9. Mizumoto K, Kagaya K, Zarebski A, Chowell G. Estimating the asymptomatic proportion of coronavirus disease 2019 (COVID-19) cases on board the Diamond Princess cruise ship, Yokohama, Japan, 2020. Euro Surveill. 2020;25(10):2000180.

10. Sakurai A, Sasaki T, Kato S, et al. Natural History of Asymptomatic SARSCoV-2 Infection. N Engl J Med. 2020;NEJMc2013020.

11. Petrilli CM, Jones SA, Yang J, et al. Factors associated with hospital admission and critical illness among 5279 people with coronavirus disease 2019 in New York City: prospective cohort study. BMJ. 2020;369:m1966.

12. Guan W, Ni Z, Hu Y, et al. Clinical Characteristics of Coronavirus Disease 2019 in China. N Engl J Med. 2020 Feb 28. https://doi.org/10.1056/ NEJMoa2002032

13. Preliminary Estimates of the Prevalence of Selected Underlying Health Conditions Among Patients with Coronavirus Disease 2019 - United States, February 12-March 28, 2020. MMWR Morb Mortal Wkly Rep 2020;69:382-6.

14. Verity R, Okell LC, Dorigatti I, et al. Estimates of the severity of coronavirus disease 2019: a model-based analysis Lancet Infect Dis 2020;20(6):66967.

15. Huang C, Wang Y, Li W, et al. Clinical features of patients infected with 2019 novel coronavirus in Wuhan, China. Lancet 2020; 395: 497-506.

16. Soni M, Gopalakrishnan R, Vaishya R, Prabu P. D-dimer level is a useful predictor for mortality in patients with COVID-19: Analysis of 483 cases. Diabetes Metab Syndr. 2020;14(6):2245-9.

17. Di Filippo L, Formenti AM, Rovere-Querini P, et al. Hypocalcemia is highly prevalent and predicts hospitalization in patients with COVID-19. Endocrine. 2020;68(3):475-478.

18. Güçlü E, Kocayiğit H, Okan HD, et al. Effect of COVID-19 on platelet count and its indices. Rev Assoc Med Bras (1992). 2020 Aug;66(8):1122-7.

19. Nunes JPL. Mortality and use of angiotensin-converting enzyme inhibitors in COVID 19 disease: a systematic review. Porto Biomed J. 2020;5(6):e085.

20. Xue Zhang, Jiong Yu, Li-ya Pan, Hai-yin Jiang, ACEI/ARB use and risk of infection or severity or mortality of COVID-19: A systematic review and meta-analysis, Pharmacol Res 2020;158:104927.
21. Pengo M, Stefanini G, Pivato C, et al. In-hospital diuretic use is associated with worse outcome in patients with Covid-19. J Hypertension 2021;39:e38.

22. di Filippo L, Formenti AM, Doga M, Pedone E, Rovere-Querini P, Giustina A. Radiological Thoracic Vertebral Fractures are Highly Prevalent in COVID-19 and Predict Disease Outcomes. J Clin Endocrinol Metab. 2021;106(2):e602-e614.

23. Liu J, Han P, Wu J, Gong J, Tian D. Prevalence and predictive value of hypocalcemia in severe COVID-19 patients. J Infect Public Health. 2020;13(9):1224-8.

24. Sun JK, Zhang WH, Zou L, et al. Serum calcium as a biomarker of clinical severity and prognosis in patients with coronavirus disease 2019. Aging (Albany NY). 2020;12(12):11287-95.

25. Di Filippo L, Formenti AM, Rovere-Querini $P$, et al. Hypocalcemia is highly prevalent and predicts hospitalization in patients with COVID-19. Endocrine. 2020;68(3):475-8.

26. Connors JM, Levy JH. COVID-19 and its implications for thrombosis and anticoagulation. Blood. 2020;135(23):2033-40. 